\title{
Autosomal dominant transmission of gouty arthritis with renal disease in a large Japanese family
}

Naoto Yokota, Hisashi Yamanaka, Yoshitaka Yamamoto, Shouichi Fujimoto, Tanenao Eto, Kenjiro Tanaka patients undergoing dialysis had gout as a primary disease. ${ }^{1}$ Several articles have described families with gout and renal failure. ${ }^{2-13}$ Richmond $e t$ al described such a family with 'familial urate nephropathy', ${ }^{2}$ while Duncan and Dixon reported a similar disease and termed it 'familial gouty nephropathy'. ${ }^{3}$ Members of these families had marked hyperuricaemia and gout even when young, and their renal function progressively deteriorated. In addition, women commonly had the disease, in sharp contrast with the rare occurrence of gout in women in the general population. In this article we describe the findings in a six generation Japanese family, many of whom had gout and progressive nephropathy; abnormal renal handling of uric acid was found in some members.

\section{Methods}

\section{CLEARANCE STUDY}

Amounts of uric acid excreted in urine and values of uric acid clearance were determined from 24 hour urine specimens obtained from subjects not receiving a purine restricted diet. The concentrations of serum and urinary uric acid or creatinine were measured by an automatic analyser (TBA-50S, Toshiba, Japan).
Activities of hypoxanthine-guanine phosphoribosyltransferase and phosphoribosylpyrophosphate synthetase were determined in
DETERMINATION OF ENZYME ACTIVITIES

Figure 1 Pedigree of a six generation fapanese family with gouty arthritis and renal disease. Roman numerals in the left margin indicate generation; arabic numerals, members of each generation. Hyperuricaemia was defined as over 0.45 mmoll/ of serum uric acid; renal dysfunction, over 133 umolll of serum creatinine.

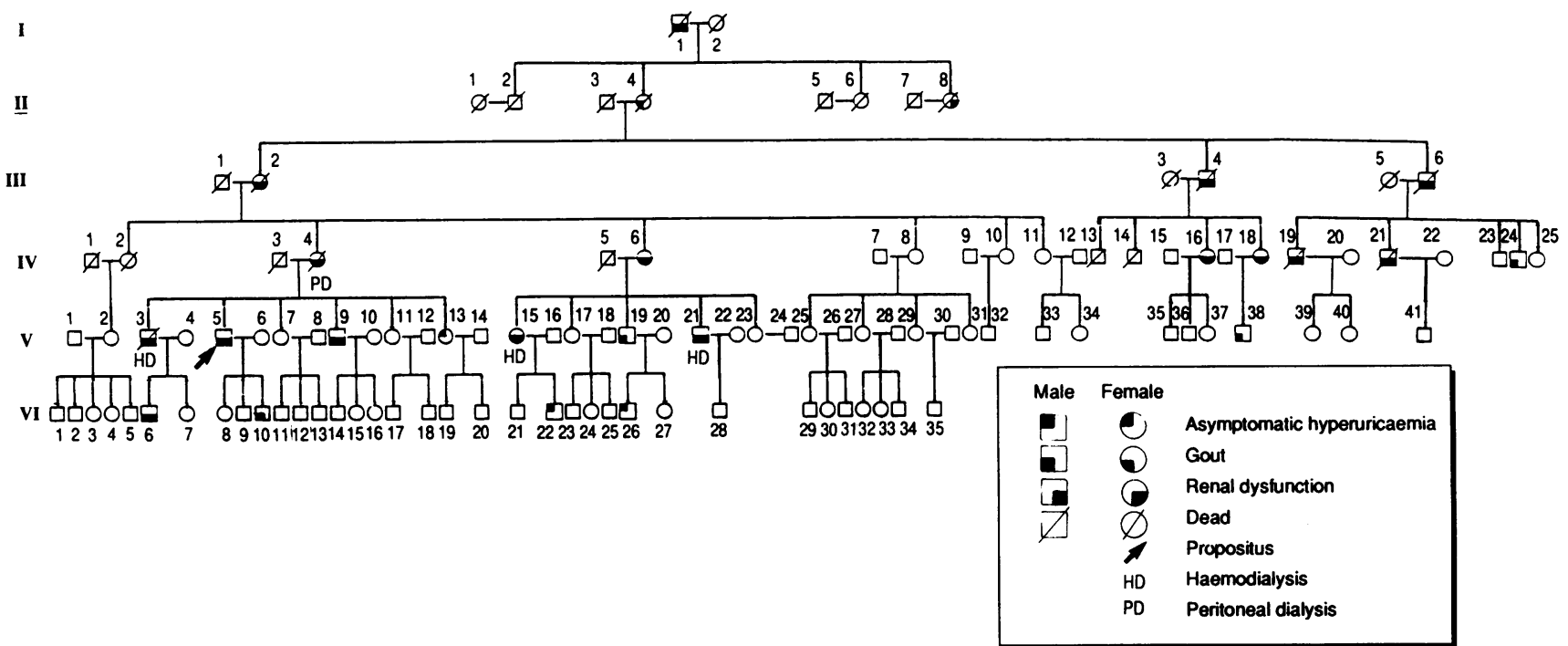

Primary gout is a metabolic disease which may be closely linked to nephropathy. As a cause of severe renal impairment, however, it accounts for only a small proportion of all cases. According to a report by the Japanese Society for Dialysis Therapy in 1989, only $0.7 \%$ of 80075
Internal Medicine

Y Yamamoto
S Fujimoto
T Eto
K Tanaka
Institute of
Rheumatology,
Tokyo Women's
College
H Yamanaka
Correspondence to:
Dr Naoto Yokota,
First Department of
Medicine, Miyazaki
College, 5200 Kihara, Japan.

Accepted for publication

19 February 1990

Y Yamamoto
S Fujimoto
T Eto
K Tanaka
Institute of
Rheumatology,
Tokyo Women's
College
H Yamanaka
Correspondence to:
Dr Naoto Yokota,
First Department of
Medicine, Miyazaki
College, 5200 Kihara,

Y Yamamoto
S Fujimoto
T Eto
K Tanaka
Institute of
Rheumatology,
Tokyo Women's
College
H Yamanaka
Correspondence to:
Dr Naoto Yokota,
First Department of
Medicine, Miyazaki
College, 5200 Kihara,

\begin{abstract}
Six generations of a Japanese family had urate nephropathy. As far as is known this is the largest family with this disease so far reported. gouty arthritis and progressive nephropathy.
Data on nine of 51 women (18\%) and 15 of 66 men $(23 \%)$ with either asymptomatic hyperuricaemia, gouty arthritis, or renal insufmen and one woman with hyperuricaemia or gouty arthritis was also examined. Urinary all subjects examined, including the young. Erythrocyte phosphoribosylpyrophosphate
synthetase and hypoxanthine-guanine phosphoribosyltransferase activities determined in been treated with allopurinol to reduce serum did not prevent progression of renal impairment. Transmission of the disease in this dominant. The data suggest that the disease in this family is the same entity as that described by other workers - that is, familial
\end{abstract}

Y Yamamoto
S Fujimoto
T Eto
K Tanaka
Institute of
Rheumatology,
Tokyo Women's Medical
College
H Yamanaka
Correspondence to:
Dr Naoto Yokota,
First Department of Internal
Medicine, Miyazaki Medical
College, 5200 Kihara,

Y Yamamoto
S Fujimoto
T Eto
K Tanaka
Institute of
Rheumatology,
Tokyo Women's Medical
College
H Yamanaka
Correspondence to:
Dr Naoto Yokota,
First Department of Interna
Medicine, Miyazaki Medica
College, 5200 Kinara, 
the erythrocyte lysate from patients and normal subjects according to the methods of Seegmiller et $a l^{14}$ and Wood et $a l^{15}$ respectively.

\section{Results}

PROPOSITUS

The propositus (a 53 year old man shown as V-5 in fig 1) attended the outpatient clinic of Miyazaki Medical College Hospital with acute arthritis in the knee. He had had a typical podagra on the right big toe at the age of 33, which was effectively controlled by colchicine treatment. After age $\mathbf{4 0}$ he had had recurrent attacks of gouty arthritis in the joints, including ankles, knees, and fingers. He had no history of haematuria, renal colic, or analgesic abuse.

On admission, blood pressure was $180 / 110$ $\mathrm{mmHg}$. There were no other remarkable physical findings. Urine analysis showed $\mathrm{pH}$ 5.0 , gravity 1.010 , protein $1+$, two to three white blood cells per high power field, five to six red blood cells per high power field, and occasional granular casts. Laboratory findings showed serum creatinine $212 \mu \mathrm{mol} / 1$, blood urea $6.7 \mathrm{mmol} / \mathrm{l}$, and haemoglobin concentration 117 $\mathrm{g} / \mathrm{l}$. Serum uric acid was $0.4 \mathrm{mmol} / \mathrm{l}$ while he was receiving allopurinol $200 \mathrm{mg} /$ day. Ultrasound echography showed bilateral contracted kidneys. Allopurinol was prescribed to treat hyperuricaemia, with both propranolol and nifedipine for hypertension control. During a clinical course of over 26 months after the start of treatment gouty arthritis did not recur. Serum creatinine concentrations, however, gradually rose to $283 \mu \mathrm{mol} / \mathrm{l}$, indicating progression of renal impairment.

FAMILY STUDY

Patients in this family first had attacks of gouty arthritis between the ages of 21 and 35 (average 26.9 years), much younger than the usual onset of primary gout. Serum creatinine concentrations exceeded $177 \mu \mathrm{mol} / \mathrm{l}$ in eight patients, and either peritoneal dialysis or haemodialysis was started for four of them. Eight subjects who died with severe renal failure were identified.

Figure 1 shows the family pedigree. Clearly, the disease causing gout/hyperuricaemia and renal insufficiency is genetic, inherited dominantly through six generations. As far as we know this is the largest family with urate nephropathy to be reported. Among the 117 members in this pedigree, $23(20 \%)$ had gouty arthritis or asymptomatic hyperuricaemia and $17(15 \%)$ had renal insufficiency. The occurrence of gout/hyperuricaemia and renal disease tended to coincide. Thus a subject with renal insufficiency almost always had gout or hyperuricaemia. Furthermore, all descendants of subjects with neither gout/hyperuricaemia nor renal insufficiency were free from related diseases. Table 1 summarises the clinical course and outcome of disease.

Renal function was evaluated by clearance studies in 10 subjects (table 2). Five of these patients had histories of gouty arthritis, while the other five had neither gout nor hyperuricaemia. Daily excretion of uric acid and fractional clearance of uric acid $\left(\mathrm{C}_{\mathrm{UA}} / \mathrm{Ccr}\right)$ were decreased in all the subjects with gout. It should be emphasised that even in a 20 year old patient with gout (VI-10 in fig 1) urinary excretion of uric acid was low. It seems that reduced excretion of uric acid is the primary cause of hyperuricaemia in this family.

To exclude the possibility of other causes of genetic hyperuricaemia and gout the activities of hypoxanthine-guanine phosphoribosyltransferase and phosphoribosylpyrophosphate syn-

Table 1 Clinical course and outcome in family members with renal disease or gout, or both

\begin{tabular}{|c|c|c|c|c|c|c|}
\hline Patient & Sex & $\begin{array}{l}\text { Blood } \\
\text { pressure } \\
\text { mmHg (age) }\end{array}$ & $\begin{array}{l}\text { Age at } \\
\text { presentation } \\
\text { with gout }\end{array}$ & $\begin{array}{l}\text { Serum creatinine } \\
\text { umolll } \\
\text { (age) }\end{array}$ & $\begin{array}{l}\text { Allopurinol } \\
\text { treatment }\end{array}$ & Outcome (age) \\
\hline $\begin{array}{l}\text { I-1 } \\
\text { III-2 } \\
\text { III-4 } \\
\text { III-6 } \\
\text { IV-4 } \\
\text { IV-6 } \\
\text { IV-19 } \\
\text { IV-21 } \\
\text { V-3 } \\
\text { V-5 } \\
\text { V-9 } \\
\text { V-15 } \\
\text { V-21 } \\
\text { VI-6 }\end{array}$ & $\begin{array}{l}\mathbf{M} \\
\mathbf{F} \\
\mathbf{M} \\
\mathbf{M} \\
\mathbf{F} \\
\mathbf{F} \\
\mathbf{M} \\
\mathbf{M} \\
\mathbf{M} \\
\mathbf{M} \\
\mathbf{M} \\
\mathbf{M} \\
\mathbf{M} \\
\mathbf{M}\end{array}$ & $\begin{array}{l}\text { NA* } \\
140 / 90(39) \\
\text { NA } \\
\text { NA } \\
190 / 110(67) \\
200 / 100(65) \\
\text { NA } \\
\text { NA } \\
210 / 120(46) \\
180 / 110(53) \\
160 / 100(49) \\
184 / 114(40) \\
176 / 112(38) \\
132 / 70(22)\end{array}$ & $\begin{array}{l}\text { NA } \\
29 \\
23 \\
25 \\
29 \\
35 \\
26 \\
24 \\
31 \\
33 \\
25 \\
22 \\
21\end{array}$ & $\begin{array}{l}\text { NA } \\
\text { NA } \\
\text { NA } \\
\text { NA } \\
\text { PD* }^{*}(67) \\
248(65), 398(77) \\
\text { NA } \\
\text { NA } \\
787(46), \mathrm{HD}^{*}(46) \\
212(53), 283(55) \\
239(49), 380(53) \\
\text { HD (42) } \\
\text { HD (40) } \\
88(22), 186(30)\end{array}$ & $\begin{array}{l}\text { No } \\
\text { No } \\
\text { No } \\
\text { No } \\
\text { No } \\
\text { Continuous from age } 65 \text { to } 76 \\
\text { No } \\
\text { No } \\
\text { No } \\
\text { Continuous from age } 53 \\
\text { Intermittent only from age } 30 \\
\text { No } \\
\text { No } \\
\text { Continuous from age } 21\end{array}$ & $\begin{array}{l}\text { Died of uraemia }(73) \\
\text { Died of uraemia }(48) \\
\text { Died of uraemia }(45) \\
\text { Died of uraemia }(53) \\
\text { Died of uraemia }(67) \\
\text { Alive (77) } \\
\text { Died of uraemia }(45) \\
\text { Died of uraemia (45) } \\
\text { Died of cerebral bleeding (54) } \\
\text { Alive }(55) \\
\text { Alive (53) } \\
\text { Alive }(55) \\
\text { Alive }(45) \\
\text { Alive }(30)\end{array}$ \\
\hline
\end{tabular}

${ }^{*} \mathrm{NA}=$ not available; $\mathrm{PD}=$ peritoneal dialysis; $\mathrm{HD}=$ haemodialysis

Table 2 Clearance studies in 10 family members

\begin{tabular}{|c|c|c|c|c|c|c|c|c|}
\hline Patient & Age & Sex & $\begin{array}{l}\text { History } \\
\text { of gout }\end{array}$ & $\begin{array}{l}\text { Serum uric acid } \\
\text { (mmolll) }\end{array}$ & $\underset{(\operatorname{mmol} / 24}{U V_{U}}{ }^{*}$ & $\begin{array}{l}C_{U A}^{*} \\
(\operatorname{ml} / \min )\end{array}$ & $\begin{array}{l}\mathrm{Ccr}{ }^{*} \\
(\mathrm{ml} / \mathrm{min})\end{array}$ & $\underset{(\%)}{C_{U A} / C c r^{*}}$ \\
\hline $\begin{array}{l}\text { IV-6 } \\
\text { V-5 } \\
\text { V-9 } \\
\text { VI-6 } \\
\text { VI-10 } \\
\text { V-2 } \\
\text { VI-1 } \\
\text { VI-4 } \\
\text { VI-5 } \\
\text { VI-23 }\end{array}$ & $\begin{array}{l}72 \\
55 \\
53 \\
30 \\
20 \\
62 \\
42 \\
31 \\
24 \\
32\end{array}$ & $\begin{array}{l}\mathbf{F} \\
\mathbf{M} \\
\mathbf{M} \\
\mathbf{M} \\
\mathbf{M} \\
\mathbf{F} \\
\mathbf{M} \\
\mathbf{F} \\
\mathbf{M} \\
\mathbf{M}\end{array}$ & $\begin{array}{l}\text { Yes } \\
\text { Yes } \\
\text { Yes } \\
\text { Yes } \\
\text { Yes } \\
\text { No } \\
\text { No } \\
\text { No } \\
\text { No } \\
\text { No }\end{array}$ & $\begin{array}{l}0.52 \\
0.42 \dagger \\
0.52 \\
0.38 t \\
0.41 \\
0.27 \\
0.39 \\
0.32 \\
0.37 \\
0.4\end{array}$ & $\begin{array}{l}1.3 \\
0.8 \\
1.4 \\
1.2 \\
2.6 \\
3.7 \\
4.8 \\
7.3 \\
6.1 \\
3.1\end{array}$ & $\begin{array}{c}0.4 \\
1.24 \\
1.43 \\
3.9 \\
5.97 \\
6.67 \\
16.65 \\
13.10 \\
17.88 \\
8.62\end{array}$ & $\begin{array}{r}10.3 \\
23.0 \\
38.2 \\
61 \cdot 2 \\
108.0 \\
78.7 \\
90.2 \\
96.4 \\
92.3 \\
80.3\end{array}$ & $\begin{array}{r}3 \cdot 88 \\
5 \cdot 39 \\
3 \cdot 74 \\
6 \cdot 37 \\
5 \cdot 53 \\
8 \cdot 48 \\
18 \cdot 46 \\
13 \cdot 59 \\
19 \cdot 37 \\
10 \cdot 73\end{array}$ \\
\hline
\end{tabular}

${ }^{*} \mathrm{UV}_{\mathrm{UA}}=$ urinary uric acid excretion; $\mathrm{C}_{\mathrm{UA}}=$ uric acid clearance; $\mathrm{Ccr}=$ creatinine clearance; $\mathrm{C}_{\mathrm{UA}} / \mathrm{Ccr}=$ fractional clearance of uric acid. †Receiving allopurinol $200-300 \mathrm{mg} /$ day. 


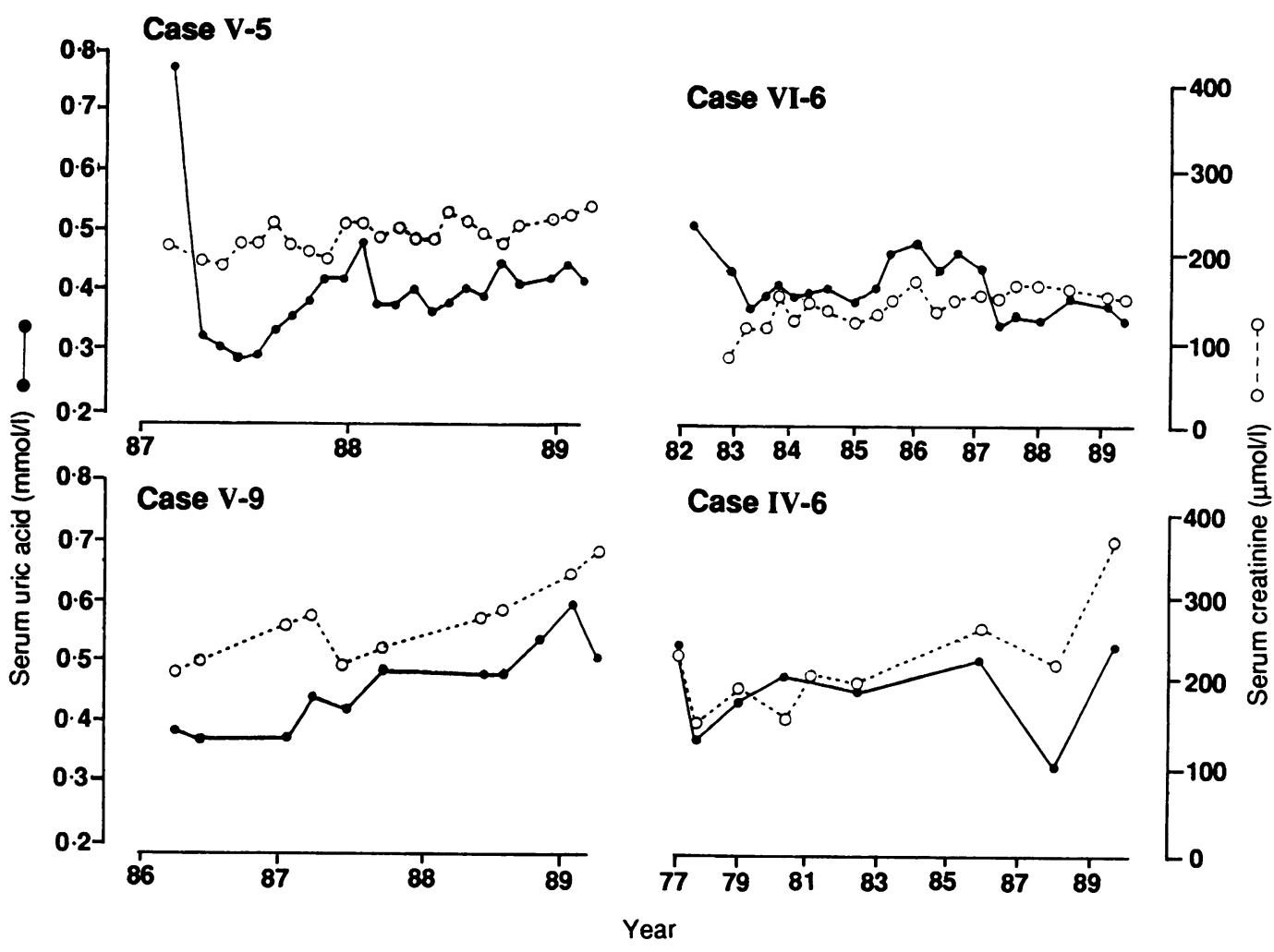

Figure 2 Clinical course of patients with gouty arthritis and renal disease. Concentrations of serum uric acid ( serum creatinine $(\mathrm{O}-\mathrm{O})$ were determined serially in these patients, all of whom had been receiving allopurinol to control hyperuricaemia.

thetase were assayed in the erythrocytes from 10 subjects in this family. There are two major purine metabolising enzymes, genetic abnormalities of which may result in overproduction of uric acid. These enzyme activities were normal, however. These results exclude the possibility of partial deficiency in hypoxanthine-guanine phosphoribosyltransferase and hyperactivity of phosphoribosylpyrophosphate synthetase as the cause of hyperuricaemia.

At least four patients were treated with allopurinol $200-300 \mathrm{mg} /$ day. Figure 2 shows the effect of this treatment on serum uric acid and creatinine concentrations. Despite control of serum uric acid concentrations with allopurinol, serum creatinine concentrations gradually increased in all patients, indicating progressive deterioration of renal function.

\section{Discussion}

In most chronic diseases serum uric acid concentrations are not greatly increased before renal function is severely impaired because reduction in the amount of uric acid filtered through the glomerulus is well compensated for by increasing tubular excretion of uric acid. ${ }^{16}$ Therefore chronic renal insufficiency from primary renal disease is a rare cause of severe hyperuricaemia or gout. On the other hand, impairment of renal function usually develops

- only at a later stage of primary gout unless hypertension or renal calculi occur. ${ }^{17} 18$ It is also rare, therefore, that young subjects develop severe renal impairment because of primary gout.

The cause of the familial disease described here could be explained neither by renal insuf- ficiency secondary to usual primary gout, nor by gout/hyperuricaemia secondary to the usual renal disease. Early onset of hyperuricaemia and gout followed by rapid development of renal impairment is a characteristic feature of this familial disease. Strict control of hyperuricaemia with allopurinol in some family members prevented gouty arthritis, but not the progression of renal impairment, indicating that hyperuricaemia is not the primary cause of this renal disease. The mechanism causing hyperuricaemia seems to be a marked reduction in urinary excretion of uric acid.

Another characteristic of this familial disease is a high rate of association with hypertension, even in those without marked renal insufficiency. Thus seven out of 14 patients with this renal disease or gouty arthritis (or both) had hypertension. One member (V-3 in fig 1) had malignant hypertension and died of cerebral bleeding at the age of 54 . Although the mechanism of hypertension in this family is not clear, ${ }^{19} 20$ it apparently modified the clinical course of the disease.

Occurrence of the disease in every generation is evidence of transmission from father to son, and approximate equivalence between sexes among affected subjects strongly suggests dominant transmission. Hypoxanthine-guanine phosphoribosyltransferase deficiency (complete or incomplete) and phosphoribosylpyrophosphate synthetase superactivity, two known causes of familial hyperuricaemia, were excluded as possible causes of the disease in this family because no supporting evidence indicated that such enzyme activities played a part in disease transmission.

The clinical and laboratory features of the 
familial renal disease described here are consistent with those reported by Richmond $e t$ al as 'familial urate nephropathy' in a white family with gout and renal disease. ${ }^{2}$ Similar conditions have been reported in families elsewhere. ${ }^{2-5} 7-13$ In most of these reports renal biopsy specimens showed non-specific tubulointerstitial nephropathy. Uric acid crystals were not identified, except for a case described by Farebrother et al. ${ }^{11}$ Richmond et al described an 8 year old boy with hyperuricaemia and a normal serum creatinine concentration. ${ }^{2}$ A renal biopsy specimen showed advanced interstitial fibrosis and tubular atrophy. Thus kidney lesions may occur before the appearance of gouty arthritis.

Dominant inheritance of the disease indicates that a single locus has an aetiological role. Among various loci related to genetic renal diseases, the locus for adult polycystic kidney disease may possibly be identical to the locus for this disease. A recent report by Mejias et al stated that hyperuricaemia and gout were common complications of adult polycystic disease. ${ }^{21}$ A marked underexcretion of uric acid was seen in the patients in this family, however, whereas most patients with adult polycystic kidney disease and hyperuricaemia excrete a normal amount of uric acid into the urine. Thus our conditions were genetically different from those of most cases. Linkage analysis using DNA probes for genetic loci and restriction fragment length polymorphism might provide further evidence on the origin and transmission of this disease.

We wish to thank Dr Jun-ichi Hayakawa, Hayakawa Orthopedic Clinic, Nichinan, Miyazaki, for providing the opportunity to study this family, Dr Naoyuki Kamatani, Tokyo Women's Medical College, for pertinent comments and suggestions, and Mr M Ohara for reading the manuscript.
1 fapanese dialysis therapy register: 1989 report. Chiba, Japan: Japanese Society for Dialysis Therapy, 1989.

2 Richmond J M, Kincaid-Smith P, Whitworth J A, Becker G J. Familial urate nephropathy. Clin Nephrol 1981; 16: 163-8.

3 Duncan $\mathrm{H}$, Dixon A S. Gout, familial hyperuricemia and renal disease. $Q$ f Med 1960; 29: 127-35.

4 Rosenbloom F M, Kelley W N, Carr A A, Seegmiller J E. Familial nephropathy and gout in a kindred [Abstract]. Clin Res 1969; 15: 270.

5 Van Goor W, Kooiker C J, Dorhout Mees E J. An unusual form of renal disease associated with gout and hypertension. f Clin Pathol 1971; 124: 354-9.

6 Thompson G R, Weiss J J, Goldman R T, Rigg G A. Familial occurrence of hyperuricemia, gout and medullary cystic disease. Arch Intern Med 1978; 138: 1614-7.

7 Simmonds H A, Warren D J, Cameron J S, Potter C F, Farebrother D A. Familial gout and renal failure in young women. Clin Nephrol 1980; 14: 176-82.

8 Warren D J, Simmonds H A, Gibson T, Naik R B. Familial gout and renal failure. Arch Dis Child 1981; 56: 699-704.

9 gout and renal failure. Arch Dis Child 1981; 56: 699-704. Weller J M. Familial hyperuricemia and renal disease. Arch Weller J $M$. Familial hyperuricet

10 Leumann E P, Wegmann W. Familial nephropathy with hyperuricemia and gout. Nephron 1983; 34: 51-7.

11 Farebrother D A, Pincott J R, Simmonds H A, Warren D J Dillon M J, Cameron J S. Uric acid crystal-induced nephropathy. Evidence for a specific renal lesion in a gouty family I Pathol 1981; 135: 159-68.

12 Bennett R M, Chait A, Lewis B. Familial hyperuricaemia and hypertriglyceridaemia. Ann Rheum $D$ is $1973 ; 32: 497-500$.

13 Hollingworth P, Scott J T. Familial gout, hyperuricaemia, and renal impairment. Ann Rheum Dis 1983; 42 (suppl): 87-8.

14 Seegmiller J E, Rosenbloom F M, Kelley W M. Enzyme defect associated with a sex-linked human neurological defect associated with a sex-linked human neurological $1682-4$.

15 Wood A W, Becker M A, Seegmiller J E. Purine nucleotide synthesis in lymphoblasts cultured from normal subjects and a patient with Lesch-Nyhan syndrome. Biochem Genet 1973; 9: 261-74.

16 Steele T H, Rieselbach R E. The contribution of residual nephrons within the chronically diseased kidney to urate homeostasis in man. Am $\mathcal{F}$ Med 1967; 43: 876-86.

17 Fessel W J. Renal outcomes of gout and hyperuricemia. $A m \mathcal{F}$ Med 1979; 67: 74-82.

18 Berger L, Yu T F. Renal function in gout. IV. An analysis of 524 gouty subjects including long-term follow-up studies. Am $\mathcal{F}$ Med 1975; 59: 605-13.

19 Hall A P Correlation among hyperuricemia, hypercholesterolemia, coronary artery disease and hypertension. terolemia, coronary artery diseas

20 Emmerson B T. Atherosclerosis and urate metabolism. Aust NZ J Med 1979; 9: 451-4.

11 Mejias E, Navas J, Lluberes R, Martinez-Maldonado $M$. Hyperuricemia, gout and autosomal dominant polycystic kidney disease. Am $\mathcal{Y}$ Med Sci 1989; 297: 145-8. 